\title{
Strategy for Implementing the Policy of Optimizing Advertisement Tax Revenues in Bandung District
}

\author{
Budi Kurniadi, Nantia Rena Dewi Munggaran, Dudi Yudhakusuma, Riefky Krisnawan, \\ Suhermanudin
}

\begin{abstract}
Regional autonomy gives freedom to the regions to explore the sources of financial revenues guaranteed by the Regional Government Law and until now each region is very dependent on the local tax sector. Various policy efforts have been made by the regional government to manage, regulate and manage local taxes, but are still not optimal. This study aims to formulate a strategy for implementing the policy of optimizing advertisement tax revenues in the Revenue and Financial Management Office of Bandung Regency. The research method used is mixed methods with qualitative and quantitative approaches (sequential exploratory). Qualitative approaches were chosen in line with the purpose of this study to uncover and illustrate a reality of public administration regarding the implementation of advertising policies through the development of concepts based on facts and data carefully and to draw meaning from ideas, attitudes and motives related to problems and research objectives, while Quantitative approach as a cross check on the results of Qualitative data analysis. The results of the study found that the effective policy implementation model for optimizing advertisement tax revenues in the Office of Revenue and Financial Management is the Strength-Opportunity (SO) strategy, which uses internal power to take advantage of opportunities. owned.
\end{abstract}

Index Terms: Optimizing tax revenues; Policy implementation; Strategy formulation

\section{INTRODUCTION}

The 1998 reforms in Indonesia, have raised hopes for autonomous regions in managing their potential optimally in realizing good public service. The condition was successfully delivered concrete steps in the formulation and evaluation of policies related to the paradigm of good governance through the implementation of the principle of decentralization. Each autonomous region is given special balance funds and grants in the form of profit sharing funds, general allocation funds (DAU) and special allocation funds (DAK) from the central government with varying amounts

Revised Manuscript Received on April 19, 2019.

Dr. Budi Kurniadi, Government Sciences program, Fakucty of Social and Political Sciences Universitas Langlangbuana Bandung Indonesia.(Email: kurnia170765@yahoo.com)

Nantia Rena Dewi Munggaran, Communication Sciences program, Fakucty of Social and Political Sciences Universitas Langlangbuana Bandung Indonesia.(Email: nantiavenus@gmail.com)

Dudi Yudhakusuma, Communication Sciences program, Fakucty of Social and Political Sciences Universitas Langlangbuana Bandung Indonesia.(Email: dudi.yudha@yahoo.com)

Riefky Krisnawan, Communication Sciences program, Fakucty of Social and Political Sciences Universitas Langlangbuana Bandung Indonesia.(Email: riefkykrisnayana@gmail.com)

Dr. Suhermanudin, Government Sciences program, Fakucty of Social and Political Sciences Universitas Langlangbuana Bandung Indonesia.(Email: mandin576@gmail.com) depending on the area, population and resources owned by each region. In general, regional financial capacity still depends on grants from the central government. This shows that the management of various regional financial potentials is still not optimal, including in the local tax sector. The regional tax that has the opportunity to increase regional revenue is advertisement tax.

The problem in Bandung district lies in optimizing advertisement tax revenue that are not optimal. This happened because (a) the potential inventory and advertisement tax assessment are weak so that the calculation of the value of the tax becomes inaccurate and there are also a tendency of fluctuations in revenues and does not make a significant contribution; (b) tax avoidance still occurs; (c) there is overlap in the issuance of advertising permits in the border area

Based on these problems, the authors set the objective of the study to find a strategy for implementing policy on optimizing advertisement tax revenues, finding meaning, data and facts through a quantitative qualitative approach related to the implementation of advertising policies at the Bandung District Revenue and Financial Management Office.

\section{LITERATURE REVIEW}

The implementation of policy is crucial and complex in the field of public policy studies, especially if faced with public desires that have a political interest. Bardach states: "It's hard enough to design public and programs that look good on paper, it's harder still pleasingliy in the ears of political leader s and the constituences to which they are responsive and at's excruciatingly hard to implementing them in a way that pleasing anyone at all, including the supposed beneficiaries or clients". Bardach also argues that political criteria associated with trust and motivation of perpetrators figures. Laws, rules, and regulations dictate acceptable alternative outcome of the political process Alternative policies should focus on political criteria values that are related to the support of policies by decision makers, public officials, the public and other sources of power in the political process [1].

Additionally, implementation is an interaction between

Published By: 
setting goals and actions directed at achieving goals. There is a linear relationship between the agreed policy objectives and their implementation. Therefore Pressman and Wildavsky argue that implementation implies the establishment of adequate bureaucratic procedures to ensure that policies are carried out as accurately as possible, then implementing institutions must have sufficient resources available, and there needs to be a clear system of responsibilities and hierarchical control to oversee implementing actions [2]. That opinion confirms that policy implementation is faced with the level of difficulties arising from the complexity of public reality, the desire of political leaders and followers who often impose their political will through a variety of well-drafted program designs but are very difficult to realize.

Thus the policy implementation process is inseparable from the various factors that surround it, both internal factors of the administrative office's bureaucratic structure that are responsible for policy programs and external factors such as the social, economic and political environment. Through the policy implementation model, the process can be explained and analyzed by looking for the interrelationships between the dimensions that make it up, so as to provide an explanation of the effectiveness of the policy.

The existing conditions of financial management, especially regional revenues in the advertisement sector in Bandung District, have not been optimal, so that their contribution is not significant to local revenue. On the other hand, there are weaknesses in the implementation of advertisements such as the cost and tax base which quite complex considering the tariff calculation is based on several criteria such as type, size, location and duration of appearance. Thus, the Grindle policy implementation model is established as an approach, because Grindle views policy implementation as a political and administrative process and develops a policy implementation dimension based on content of policy and context of implementation (implementation conditions) that are still very relevant to be used as an approach to bureaucratic problems.

Based on the illustration on the policy implementation model as a political and administrative process explains that content of policy consists of dimensions:

(1) Interest affected;

(2) Type of benefit;

(3) Extent of change envisioned;

(4) Site of decision making;

(5) Program implementorts; and

(6) Resources commited

The implementation of the policy as a political and administrative process is described in the form of a scheme as shown in the following figure:

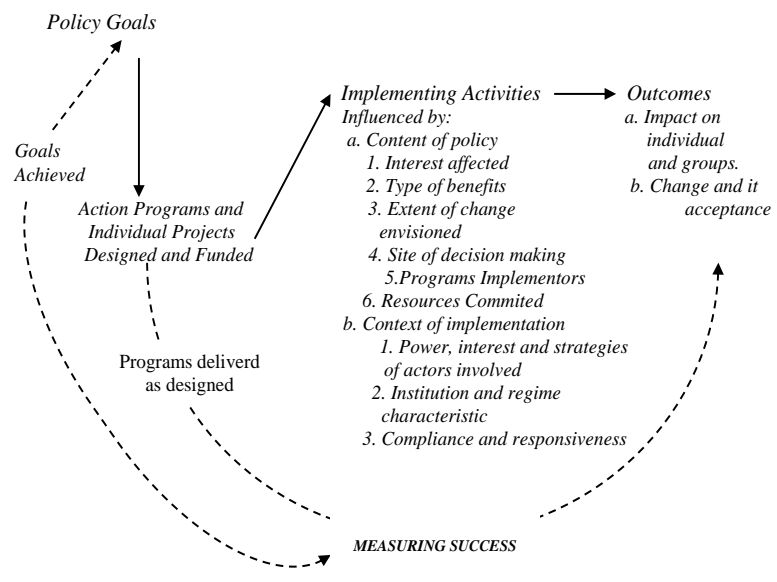

\section{Figure 1 Implementation as a Political and Administrative Process [3]}

Problems related to implementation are maintaining balance in ensuring the responsiveness of the implementers to prove flexibility, support and feedback. While, at the same time must keep control over the distribution of resources to achieve goals. To achieve these objectives, the political intelligence needed in order to take into account the possibility of a response, the capacity and skills of the actors involved in achieving the program goals that come into contact with the environment policy.

Based on these concepts, it can be explained that the policy implementation process is inseparable from a variety of factors, both internal structural factors such as administrative bureaucracies that are responsible for policy programs and external factors such as the social, economic and political environment. Through the Grindel policy implementation model, the policy implementation process can be explained and analyzed by looking for the interrelationships between the dimensions that shape it, so as to provide an explanation of the effectiveness of the policy.

Jones and Plenbury state that effectiveness in failure of an organization in achieving its goals, this means that effectiveness is a success or failure of an organization in achieving a goal [4], while according to Steers "Effectiveness should be judged on the goals that can be implemented and not the concept of maximum goals"[5] it means that effectiveness must be assessed from goals that can be implemented and not on the concept of maximum goals. Thus effectiveness is a measure of how far the organization has succeeded in achieving goals that are feasible. Both of these views illustrate a concept of the effectiveness of an organization with all its limitations in achieving its goals or goals both its success and failure.

There are several basic principles in the regional revenue management system, are: (1) Expansion of the revenue base; (Expansion of revenue base); (2) Controling for leakage income (Control of income leakage); (3) Administration of income and increase efficiency (Increased efficiency of revenue administration); (4) Transparency and accountability (Transparency and accountability) [6]. 
Regarding the optimization of advertisement tax sector revenue in the implementation of strategic management which is a stream of actions and decisions towards effective strategy planning is very helpful in achieving the program objectives, because the strategy management process is a strategic way of setting results and making strategic decisions. strategic management is the flow of decisions and actions that lead to the development of effective strategies to help achieve goals. Strategic management processes are ways in which strategic goals and strategic decisions are made [7].

The strategy management process consists of three stages, are strategy formulation, strategy implementation, and strategy evaluation. Acceleration in optimizing advertisement tax revenue will depend on the implementation strategy chosen and considered appropriate in accordance with internal and external conditions [8]. Another opinion stated the strategy is an integrated and comprehensive plan that links the company's strategic advantages with environmental challenges and is designed to ensure that the company's basic objectives are achieved through proper execution by the organization [9]. This opinion provides an understanding that the strategy is an integrated and comprehensive plan that relates to the strategic advantage of the organization with challenges that come from the environment and designed to ensure the achievement of goals.

Based on the theoretical study, the research framework model was proposed as shown in the following figure:

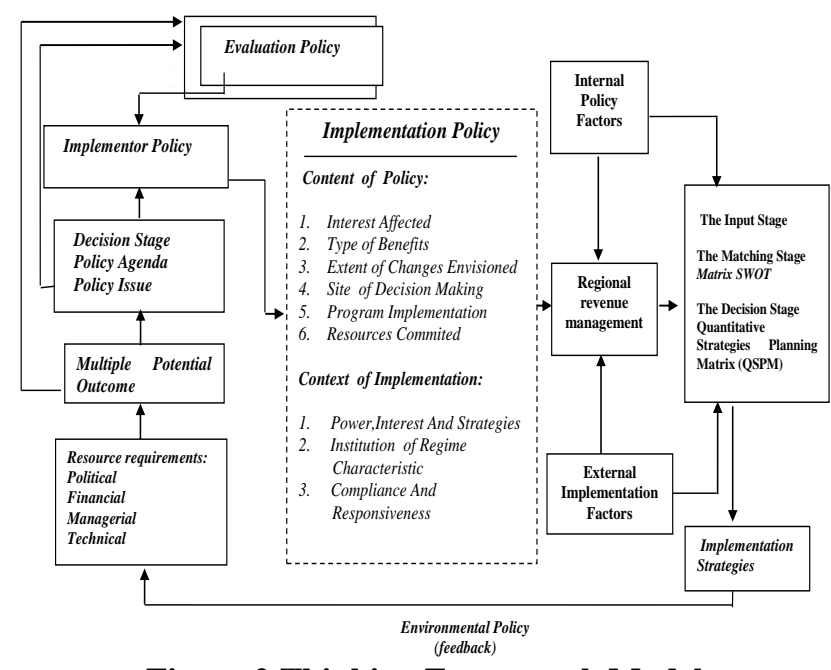

Figure 2 Thinking Framework Model

\section{METHODOLOGY}

This study uses mixed methods between qualitative and quantitative research methods. In a mixed methods study, researchers used a qualitative or quantitative approach depending on the type of design used mixed methods. In a sequential design, literature served in each phase in a manner consistent with the type of design used in that phase [10].

The statement is related to Neuman which emphasizes that qualitative and quantitative research differ in many ways, but they complement each others, as well. The priority of this research is more at the stage Triangulation in the classic sense of seeking convergence of result and the mixing process between these two methods occurs when researchers linked between qualitative data analysis and quantitative data collection [11]. This is in accordance with Creswell that, sequential design of exploration or design exploration also uses sequential time. In contrast to explanatory design, exploration design begins with and prioritizes the collection and analysis of qualitative data in the first phase, then conducts the second phase of quantitative data analysis to test or generalize initial findings. Researchers then interpret how the quantitative results built on initial qualitative results.

\section{RESULT AND FINDING}

Based on the results of the study through a qualitative approach with in-depth interviews and participant observation and triangulation of data for the validity of the information obtained shows that in The Office of the Revenue and Financial Management Bandung District has several strengths, among others are executing ten types of regional taxes and retributions as regional authorities; there are local regulations that ensure and organize various activities of advertisement taxation; establishment of Technical Implementation Units of the Regional Tax Service as technical implementers; potential stakeholders as advertisers; and political support of the legislature in the formulation of regional policies.

Its weaknesses are the weak enforcement of rules and the socialization of advertisement tax policies; there are no implementation guidelines and controls on how to run advertisements to the lowest government hierarchy; there are no commitments from the leader and policy implementer; there are no awareness and compliance of taxpayers in paying taxes.

There are opportunities that are legislation concerning Fiscal Decentralization for Regional Governments; increase in advertisement tax revenues in accordance with regional \& inter-regional potential; acceleration of regional development and utilization of promotional media; coordination and cooperation in the regional government and between regional governments; progress and utilization of science and technology; and stakeholders that continue to increase.

And finally, challenges or threats include political interests in the administration of billboards; harmonization of regulations relating to the implementation of billboards and limited operational support facilities.

\section{A. Effective Strategies in Implementing Advertising Policy} in the Revenue and Financial Management Office of Bandung District

Strategy analysis and choice of strategies try various best alternative ways for the region in an effort to realize the mission and goals.[12] The application for determining the main strategies based on this concept is done through the use of several matrices with the following three stages of implementation. 


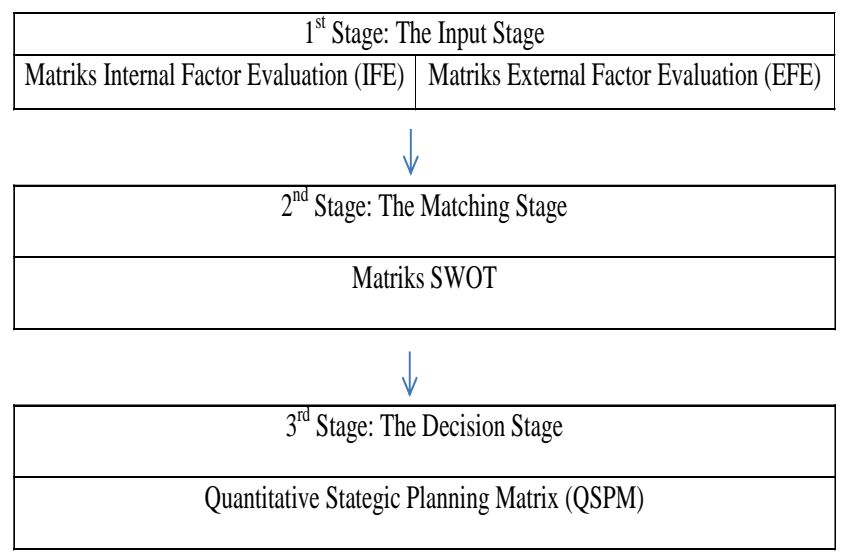

Figure 3 Stages of Strategy Formulation (Source: David, 2004)

Basically, this strategy formulation is not just an activity of collecting data, but also an activity of classification and pre-analysis. At this stage the data is divided into external and internal data. In evaluating strategic factors using a matrix of external strategic factors and internal strategic factor matrices. After establishing the strengths and weaknesses between internal factors and external factors, then compiling the results of the analysis through an Internal Factor Evaluation (IFE) and External Factor Evaluation (EFE) procedure. The aim is to see the position of each factor that has been included in strengths, weaknesses, opportunities or challenges after weighting, rating, and valuation.

The data used consists of primary data and secondary data. Survey research is conducted to collect primary data through distributing questionnaires to 40 respondents determined by cluster sampling. The distribution of this questionnaire aims to obtain information about the weight, value (rating), and Attractiveness Score (AS) that will be used in the next analysis phase.

\section{Matrix Internal Factor Evaluation (IFE)}

The results of the Internal Factor Evaluation (IFE) analysis, in addition to getting the biggest score order as the basis for determining the strength factor that affects the income from the advertisement tax sector, are also to find out internal weaknesses that greatly affect the optimization of advertisement tax revenues.

To determine the order of the biggest score is weighted by looking at the urgency of each factor. Weighting and rating are based on the results of questionnaires. After the respondent gives the weight based on the criteria, then normalization is carried out for each factor. After that, processing is carried out like the provisions used that the number of weights in this IFE matrix is 1.00.

The value category for this IFE matrix is:

- $\quad$ Poor: 1.00-1.99,

- Median: 2.00-2.99,

- $\quad$ Strong: 3.00-4.00.

From the results of IFE analysis, it can be seen that the value for the Office of Revenue and Financial Management in Bandung District from the Advertising sector is at an average position $(2,892)$. These results indicate that the internal position of the Revenue and Financial Management
Office of Bandung District has a strong ability to develop its potential or strength in overcoming existing weaknesses. Based on the results of the calculation, the factors that will be input into the SWOT matrix can be determined (at the next analysis stage). there are 5 (five) factors that have a potential value of weighting. For strength, the factors taken are 5 (five) factors that have the greatest weight, and for weaknesses because the factors found are less than 5 , then all are included in the next analysis phase. Thus the internal factors that are input into the SWOT matrix analysis are:

\section{Strength:}

1. Executing ten types of regional taxes and retributions as regional authorities.

2. Local regulations that ensure and organize various activities of advertisement taxation.

3. Establishment of Technical Implementation Units of the Regional Tax Service as technical implementers.

4. Potential stakeholders as advertisers.

5. Political support of the legislature in the formulation of regional policies.

\section{Weakness:}

1. The weak enforcement of rules and the socialization of advertisement tax policies.

2. Implementation guidelines and controls on how to run advertisements to the lowest government hierarchy.

3. Commitments from the leader and policy implementer.

4. Awareness and compliance of taxpayers in paying taxes.

\section{Matrix External Factor Evaluation (EFE)}

The External Factor Evaluation (EFE) analysis results in addition to getting the biggest score sequence that is an opportunity, also to find out the challenges that greatly influence the achievement of advertisement tax in Bandung District. To determine the order of the biggest score is done by weighting and seeing the urgency of the challenge. Weighting and rating are based on the results of the questionnaire. After the respondent gives weight then normalization is carried out for each factor. After that, processing is carried out like the provisions used that the number of weights in this EFE matrix is 1.00.

The value category for this EFE matrix is:

- $\quad$ Poor: 1.00-1.99,

- Median: 2.00-2.99,

- $\quad$ Strong: 3.00-4.00.

From the results of the analysis, it can be seen that the value for EFE is at an average position $(2,270)$. This shows that externally the Revenue and Financial Management Office of Bandung Regency is able to take advantage of existing opportunities and avoid existing challenges. The values of each matrix above show how to react to their internal and external factors.

Based on the results of the above calculations, the factors that will be input into the SWOT matrix can be determined (at the next analysis stage). The factors taken are 5 factors 
that have a potential value of weighting. For opportunities, the factors taken are 5 factors that have the greatest weight, and for challenges because the factors found are less than 5 , then all are included in the next analysis phase. The external factors that are input into the SWOT matrix analysis are:

\section{Opportunity:}

1. Legislation concerning Fiscal Decentralization for Regional Governments

2. Increase in advertisement tax revenues in accordance with regional \& inter-regional potential

3. Acceleration of regional development and utilization of promotional media

4. Coordination and cooperation in the regional government and between regional governments

5. Utilization of science and technology

6. Advertising committee stakeholders continue to increase

\section{Challenge/Threat:}

1. Guidelines for implementing supervision and control of the administration of billboards to the lowest government hierarchy;

2. Harmonization of regulations relating to the implementation of advertisements;

3. Limited operational support facilities.

\section{The Matching Stage}

The purpose of this matching stage is to produce a viable alternative strategy, not to choose or determine which strategy is the best. The matching stage of the strategy formulation framework is carried out using the SWOT matrix. In the use of the SWOT matrix it is determined by information obtained from the input stage to match internal strengths and weaknesses with external opportunities and challenges. Matching internal and external critical success factors is the key to effectively producing viable alternative strategies and is a difficult part of developing a SWOT matrix, because it requires good judgment and no best match. Therefore not all strategies developed in the SWOT matrix will be selected to be implemented.

The next step is to plotting into the SWOT diagram and look for the diagonals. The results of plotting are as follows:



Note :

$\mathrm{E}=$ is a diagonal cut $\mathrm{AC}$ and $\mathrm{BD}$

$\mathrm{A}=$ have coordinates $(2,423 ; 1,048)$;

$\mathrm{B}=$ have coordinates $(2,423 ; 0,422)$

$\mathrm{C}=$ have coordinates $(0,468 ; 0,422)$

$$
\mathrm{D}=\text { have coordinates }(0,468 ; 1,856)
$$

For completing the analysis of each quadrant, can be calculated as in the table below:

\begin{tabular}{|l|c|l|l|}
\hline Quadran & Point position & Large & Ranking \\
\hline I A & $(2,423 ; 1,048)$ & 2,539304 & 1 \\
\hline II B & $(2,423 ; 0,422)$ & 1,022506 & 2 \\
\hline III C & $(0,468 ; 0,422)$ & 0,197496 & 4 \\
\hline IV D & $(0,468 ; 1,856)$ & 0,868608 & 3 \\
\hline
\end{tabular}

\section{Decision Making Stage}

The techniques in the matching phase described before produce a viable alternative strategy. The next step is making decisions using QSPM or Quantitative Strategic Planning Matrix (David, 2004: 198-207). The use of this matrix targets to indicate which alternative strategy is best to be selected using information from the input stage and the previous matching stage. QSPM is a tool to objectively evaluate alternative strategy choices based on internal and external factors that have been previously identified.

Conceptually the purpose of the QSPM is to establish the relative attractiveness of the various strategies that have been selected on the SWOT matrix, to determine which strategies are considered the best for implementation by using assessment in selecting the alternative strategy. QSPM is made by giving the Attractiveness Score (AS) value of each internal and external factor to each proposed strategy.

- AS assesses how the influence of a factor on alternative strategies. US values range from 1 to 5 , provided that::

$1=$ very uninfluential,

$2=$ no effect,

3 = quite influential,

4 =. take effect

$5=$ very influential

- The AS value is then multiplied by the priority weight of each internal and external factor to obtain the Total Attractiveness Score (TAS).

- This AS value is obtained from the results of questionnaires, and the weight values of each internal and external factor used in the QSPM matrix are taken from the IFE and EFE matrices.

- The final step is to add the value of TAS (weight $\mathrm{x}$ AS) to each alternative strategy.

- $\quad$ To find out the best strategy can be seen from the results of the QSPM analysis which gets the highest TAS from several alternative strategies that have been chosen.

(Source: Result Analysis, 2018)

Based on the results of QSPM for SO above, SO strategy is formulated as follows:

a. Compile and revise Regional Regulations and Regents of the Regent regarding regional taxes that are not in accordance with current conditions to expand expansion of revenue base (S1, S2, S3, S5; O1, O5, O6) 
International Conference on Recents Advancements in Engineering and Technology (ICRAET-18) |15th and 16th March 2019|Siddhartha Institute of Technology \& Sciences, Telangana, India.

b. Decentralization of authority on advertisement tax collection on Technical Implementation of Regional Tax Units. (S2, S4, S5; O3, O5)

c. Increased coordination and commitment of regional government leaders through inter-regional MOUs to increase the potential and income of the advertisement tax sector between regions. (S3, S4, S5; O1, O5)

Utilization of information technology in the implementation, supervision and control of advertisement tax collection (S2, S3, S5; O5, O6)

Based on the results of QSPM for WO, the WO strategies are formulated, as follows:

a. Controlling the system and bill collection tax procedure (W1; O1);

b. Managerial tax capacity enhancement for policy implementing officers in various income and financial education / training programs. (W2; O1, O5);

c. Establish new tax collection strategies to design development programs in accordance with the demands of the community. (W1, W3; O1, O5);

d. Organizing socialization / technical guidance for SOPD and stakeholders (W3, W4; O1, O2, O4, O5)

Based on the results of QSPM for WT, the WT strategy is formulated, as follows:

a. Compile the Standard Operating Procedure (SOP)

b. Increase utilization of the company's data base to explore new taxpayers. (W3; T3);

c. Periodically evaluate advertisement tax policies (W3, W4; T1, T3);

d. Compilation of Regent Regulations regarding Mapping of billboard zoning arrangements to safeguard the aesthetics of the city as well as avoiding community losses from billboard installation activities. (W4; T1, T3)

Based on the analysis of the quantitative strategy planning matrix (QSPM) above, the results show that the policy implementation strategy recommended as a priority is the Strength - Opportunity (SO) strategy with the acquisition of TAS of 19.39, where there is a large potential advertisement tax that can still be the management was explored and optimized by taking advantage of opportunities from considerable external conditions in Bandung District.

B. Policy Implementation Based on Stakeholders' Assessment

Based on field findings regarding the implementation of advertising in Bandung District, to complete these findings, authors cross-checks with relevant stakeholders. To measure the assessment of respondents' answers to the questionnaire, the authors classify the interval lines as follows:

Interval distance for 20 questions with 40 respondents:

Minimum Index Value $=$ Minimum Score $x$ Number of Questions x Number of Respondents $=1 \times 20 \times 40=800$

Maximum Index Value $=$ Maximum Score $\mathrm{x}$ Number of Questions x Number of Respondents $=5 \times 20 \times 40=4.000$

Interval $=$ Maximum Index Value - Minimum Index Value

$$
=4.000-800=320
$$

Distance interval $=$ interval: level (5)

$$
=3.200: 5=640
$$
for advertisement tax collection (W2; T1);



The total score of 20 items in question regarding the dimensions of Grindle's policy implementation provides clues that content of policy and context of implementation in the implementation of billboards in the Revenue and Financial Management Office of Bandung Regency are not optimal with the classification of respondents' answers in a Good Enough range.

\section{Relationship of Research Findings with the Theory Used}

Grindle views policy implementation as a political and administrative process [13]. In the political situation, the policy issued was put forward by Bardach in Patton \& Sawicki built in the political arena, so that implementing the policy should pay attention to the support of political parties and support against it. The political implications of the policy are explicitly contained in the basis of decisions in maintaining, institutionalizing, and expanding programs that are considered successful and completely modifying or leaving programs deemed to be failed. In this context Bardach argues that the political criteria deal with the beliefs and motivations of actors. Laws, rules and regulations that specify bounds on acceptable alternative results from the political process. The political criteria in this regard relate to the support of policies by decision makers, public officials, the public, and other sources of power in the political process. Various provisions and regulations as a result of the political process circle will reflect the sincerity and motivation of the actors involved in the political process circle will guarantee the legality of a policy [14].

Extensively, political aspects can be assessed through the extent to which the program receives the attention and support of decision makers, public officials, the public and other stakeholders in the political process. As a consequence of policy alternatives should focus on political judgment. The political criteria in this regard relate to the support of policies by decision makers, public officials, the public, and other sources of power in the political process.

Support from the central and regional legislatures (DPR and DPRD) in the form of policy products as priority programs of the central and regional governments shows the sincerity of this. Other support originating from the community and the business world is related to innovation in the pattern of financing and management.

Government has an important role in realizing advertisement tax policy because it is related to the provision of billboard space, procurement of financial budgets and in determining the amount of tax value. So as to optimize its services, it requires political support from all parties both in building facilities and infrastructure or in encouraging conducive regional income.

Coordination that can guarantee the existence of 
cooperation between regions that have relevance in overcoming advertisement problems will produce multiplier effects both on long-term management (exit strategy) and effectiveness and efficiency. should advertisement management approaches integrate aspects of billboard management planning with other aspects of urban development that allow the opening of opportunities for all interested parties to be involved in the planning and decision making process.

In this context, simultaneous consideration of economic, environmental, social and institutional aspects, finance and technical aspects is a prerequisite that should be integrated comprehensively. In some cases, the problem of advertising has caused violations both related to rights to the environment as part of economic, social and cultural rights, as well as civil and political rights. The issue requires an evaluation of approaches that should be carried out by both the government and the private sector. This approach is considered important because it can affect the emergence of political problems with decision makers or the party considered responsible for overcoming the impact it has caused. So that in order to solve this problem well, the local government needs to take social and political approaches so that all parties can understand and at the same time be expected to support it. Thus, the support of optimal political aspects through strengthening efforts to formulate new strategies in managing advertisement tax is expected to be able to overcome various things that have not been accommodated in local government policies so that they can make a positive contribution in facing obstacles in implementing policies.

Based on the theory of policy implementation approach from Grindle on this research problem, it was concluded that the optimization of advertising tax revenue can be achieved if the dimensions of content of policy are developed by: (1) attitudes and ethical behavior dan (2) policy makers acceptability. While in the context of implementation dimensions are (1) evaluation of a holistic policy; (2) coordination among local governments and interinstitutions, and; (3) law enforcement.

The meaning of the results of this study is that Grindle's policy implementation theory will be more effective as an approach for optimizing advertisement tax revenues if the theoretical dimensions are developed based on empirical data in the field regarding the object under study. Looking at the existing conditions, implementation and policies taken steps that must be taken by the Revenue and Financial Management Office of Bandung Distric so that in the future requires a larger budget to make policy changes, improvement of the strategy will be directed at the domain that is oriented to renewal and maintenance or maintenance and termination. A program might be expanded to reach all service areas or be developed so that a good strategy can be used for a longer period of time or a wider geographical area.

Referring to the characteristics of policy succession, the assessment or evaluation of advertisement tax policies can be seen through who the policy makers are, the extent to which policy processes and the substantive results of the policy succession process are established so that old policies that are not suitable can be replaced by new policies. In that context according to the statement Hoogwood \& Peters can lead to:

a. Replacement of one policy / program / organization with another (linear);

b. Repacking a number of policies / programs / organizations into one whole unit (consolidation);

c. Revision of a policy / program / organization into a number of separate components (Splitting); and

d. Complex combination of other types of succession (Non Linear) [15].

These changes can be made by taking alternative types of changes that are possible, one of which is an incremental change in existing policies in which the policy is not changed entirely but only a few parts are carried out changes. Through these policy changes, it is expected to increase:

1) Factors in policy ability in solving problems in terms of improving the social conditions that are targeted by the program;

2) Policy ability factor to be managed;

3) Weaknesses that may exist during the policy implementation process take place;

4) Political power / political support that can strengthen institutions and networks;

5) Awareness of group groups where the policy is intended, for example group pressure such as student groups, politics, society and the international community and others on the negative impact of policy;

6) Periodic and integrated program monitoring

To realize its effectiveness, the management can be used to understand how the policy mission is actually in the interests of local governments, relevant stakeholders and the community and examine whether the strategy developed is feasible to implement so that its utilization has added value to local governments, relevant stakeholders and the community.

\section{CONCLUSION}

The conclusion of this study is that an effective policy implementation model for optimizing advertisement tax revenue in the Revenue and Financial Management Office of Bandung Regency is a Strength-Opportunity (SO) strategy, which uses internal power to take advantage of existing opportunities.

\section{REFERENCES}

1. CV Patton. DS Sawicki. Basic methods of policy analysis and planning. New York: Prentice Hall: Englewood Cliffs.Plenbury. 1986. Pp 157-163.

2. FM Fischer. J Gerald. SM Sidney. Handbook of public policy analysis: theory,politics and methods. Boca Raton, London, New York : CRC Press Taylor And Francis Group. 2007. p.91.

3. SM Grindle. Politics and policy implementation in the third world. New Jersey : Princeton University Press. 1980. P.8-11

4. MW Plenbury. Management accounting in the public sector. London. Pittman. 2000. p.12.

5. RM Steers. Organizational efftectiveness: a behavioral 
International Conference on Recents Advancements in Engineering and Technology (ICRAET-18) |15th and 16th March 2019|Siddhartha Institute of Technology \& Sciences, Telangana, India.

view.Santa Monica California: Goodyear Publishing Company, Inc. 1997. p.5

6. MW Plenbury. Management accounting in the public sector. London. Pittman. 2000. p.18-19.

7. LR Jauch. WF Glueck. Manajemen strategis dan kebijakan perusahaan. $3^{\text {rd }}$ Ed. Jakarta. Erlangga. 1998. p.6.

8. FR David. Strategic management 4th.Ed. New York: Mac Millan Publishing Company. 2004. p. 6-7.

9. LR Jauch. WF Glueck. Manajemen strategis dan kebijakan perusahaan. $3^{\text {rd }}$ Ed. Jakarta. Erlangga. 1998. p.7.

10. JW Creswell. Research design: qualitative and mixed approach. USA: Sage Publication. 1994. p.32.

11. LW Neuman. Basic of social research qualitative and quantitative approaches. 2nd Ed. University Of Wiscosin Whitewater USA : Pearson Education,Inc. 2007. p.139.

12. FR David. Strategic management 4th.Ed. New York: Mac Millan Publishing Company. 2004. p. 178.

13. SM Grindle. Politics and policy implementation in the third world. New Jersey : Princeton University Press. 1980. p.8.

14. CV Patton. DS Sawicki. Basic methods of policy analysis and planning. New York: Prentice Hall: Englewood Cliffs.Plenbury. 1986. p.156-167.

15. BW Hoogwood. BG Peters. Policy dynamics. New York: Wheatsheaf Books, Brighton, Sussex and St Martins Press. 1983. p.131

\section{AUTHORS PROFILE}

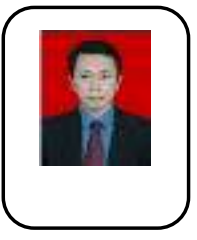

Dr. Budi Kurniadi, M.Si. The author was born in Sukabumi District on July 17, 1965. Educationa experience: Graduated from the Pelabuhan Ratu II Elementary School in Sukabumi Regency, Mardiyuana Sukabumi Catholic Middle School, Sukabumi BPK-KPS Christian Middle School, Program in the Department of Government Science, Faculty of Social and Political Sciences, Langlangbuana University (UNLA) Bandung, Master Program (S-2) in Social Sciences in the Main Study of Administrative Sciences at the Postgraduate Program at Padjadjaran University (UNPAD) Bandung, Doctoral Program (S-3) in Social Sciences in the Field of Main Studies in Public Administration Postgraduate University Pasundan (UNPAS) Bandung. Job Experience: Permanent Teaching Staff in the Government Science Study Program, Faculty of Social and Political Sciences, Langlangbuana University (UNLA) Bandung since 1989 - present. Experiences in Scientific Research and Work: Analysis of the Implementation Factors of Advertising Management Policy (2017), Development Coordination of Tourism Objects of Damar Peak in the Jatigede Reservoir Area of Sumedang Regency (2017), Young Generation in Political Ethics Perspective (2018), Indonesia Political Development: Democracy Political Parties in The Political Education Persepective (2018), Bureaucratic Reform, Ethics, and Neutrality of the State Civil Apparatus (2019). Organizational Experience: Members of PERSADI West Java Region, ISI Members of West Java Region, Members of AIPI Bandung Branch, Members of the Republic of Indonesia Brotherhood Lecturers (PDRI), Members of KAPSIPI, APSIPI Members, Expert Staff at Commission X of the Republic of Indonesia 2006-2008. Email address: kurnia170765@yahoo.com

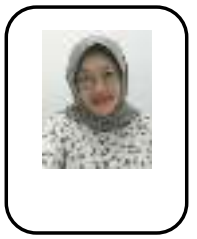

Nantia Rena Dewi Munggaran, S.S., M.I.Kom. The author was born in Bandung on December 15, 1970 Born in a family of artists with very strong traditional culture, it took her to study undergraduate programs in Sundanese Literature, Padjadjaran University. However, his interest in the world of business and entrepreneurship made her choice to study for the Business Communication Masters program at Padjadjaran University. With this educational background, she not only researches culture, but also is interested in the world of media, advertising, communication management, and being an observer of how the government communicates information about its policies to the public. several of his papers have been published in chapter books as well as national and international scientific journals. Now, he works as a lecturer at the Langlangbuana University Faculty of
Communication and nantiavenus@gmail.com

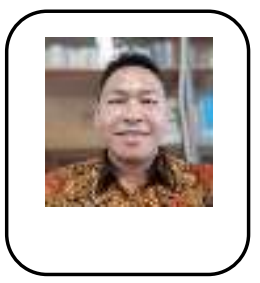

Dudi Yudhakusuma, S.IP, M. I.Kom, a graduate of the University of Pasundan Bandung (S1) majoring in International Relations, and then continuing his master's degree at Padjadjaran University in Bandung, majoring in Communication Sciences. He is interested in the fields of communication, broadcasting and media. The media world is inseparable from the world of advertising, how the appearance of ads to be attractive and beautiful to look at. In terms of media communication, the world of advertising also emphasizes the content of the message to be delivered to the public. One of my writings on media is related to news in the world of Radio news, "Editorial policy in reporting at 107.7 PRFM News Channel Bandung". Born in Situbondo, East Java 17, November 1974, I dedicated myself to be a Lecture at University of Langlangbuana Bandung since 2013. Related to my writing about "Strategy for implementing the policy of optimizing the Tax revenues in Bandung District advertisement", the Bandung Regency government policy in optimizing revenue from advertising taxes really needs to be improved, because it is still there are some weaknesses, namely:

1. Weak Enforcement and Dissemination of Advertising Tax Regulations

2. Guidelines for implementing supervision and control of the administration of billboards to the lowest government hierarchy

3. Commitment of leaders and implementing policies

4. Awareness and compliance of taxpayers (stakeholders) pay taxes

Email Address: dudi.yudha@yahoo.com

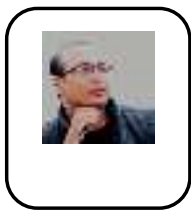

Riefky Krisnawan, S.Sos., M.Sn. born in Bandung on October 2, 1975, completed a bachelor program majoring in environmental communication studies at the Faculty of Communication Science, Padjadjaran University, Bandung, Indonesia. He currently works as a lecturer in communication science major at the Faculty of Social and Political Science, Langlangbuana University, Bandung. Now he holds a position as Deputy Dean III in Student Affairs. Completed Masters program majoring in Art Creation at the Indonesian Arts College, now called ISBI (Indonesian Cultural and Art Institute). He lectures material related to communication and art, such as photography, photo journalism, film production, and cultural communication

A researcher, a lecturer as well as an art performer, conducts a lot of researches in communication, art, and culture fields relating to communication disciplines. He focuses on studying cultural communication and his articles that have been published in national journals are crosscultural and factual facts about ethnic Chinese in Indonesia as evidence of cross-cultural communication; understanding of communication within the organization for the basis of shaping one's leadership in an organization; the role of media literacy in interpreting political marketing messages; and the relationship of public service communication with customer satisfaction. Email address: riefkykrisnayana@ gmail.com

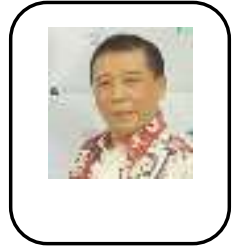

Dr, Suhermanudin, SH, M.Si. The author wa born December 13, 1962 and completed his doctora studies in the Pasundan University majoring public policy program. He is also active in the world of practical politics.. He was once the head of the General Administration Bureau and the Public Relations and Cooperation Bureau at Langlangbuana University. Currently he is a senior lecturer at the Langlangbuana University Faculty of Social Sciences and Political Sciences. He is active in various studies related to law and public policy and provides community service by providing legal counseling as well as helping small traders and farmers around Lembang, West Java, Indonesia. Email address: mandin576@gmail.com 